\title{
2.5\% pay award: BDA calls for consistency on above-inflation uplifts
}

The British Dental Association (BDA) has called on Government to deliver a consistent approach to pay, following confirmation of an above inflation pay award from Health Secretary Matt Hancock MP.

The announcement will see $2.5 \%$ uplift on pay backdated to April, with no staging. This will apply to community dentists, with a final uplift to contract values for general dental practitioners to be confirmed following a consultation on expenses. Hospital dentists will see a $2.5 \%$ uplift in basic pay, but with no increase in their clinical excellence awards, meaning an overall uplift of $2.35 \%$.

The pay award meets the recommendations made in the 47th report of the Review Body on Doctors' and Dentists' Remuneration (DDRB) in full, and is the first since 2008/9 in England above
$2 \%$, and the first above-inflation increase since 2005/6.

The BDA have supplied DDRB with evidence of the deteriorating situation on recruitment and retention in general dental services across England, with 75\% of NHS practices reporting they are struggling to fill vacancies last year - rising to $84 \%$ among those with the highest NHS commitments. $59 \%$ of NHS dentists have reported plans to leave the service or scale down commitment in the next 5 years, rising to $67 \%$ among those doing the most NHS work.

The BDA has focused press and political attention on how failure to deliver reform combined with a $35 \%$ real-terms collapse in practitioner incomes is now jeopardising the long-term sustainability of NHS dentistry. It has insisted that today's increase must not be a one-off, and should send a clear signal to devolved administrations. BDA Vice Chair Eddie Crouch said: 'Pay uplifts on the right side of inflation shouldn't be exceptional and represent a bare minimum in terms of government's duty of care to NHS dentists.

'We have taken evidence from our members on a recruitment and retention crisis to pay review bodies, to the press, and parliamentarians. We have shown how a decade of pay restraint has put the future of this service in doubt. And we will not change tack.

'This approach cannot be a one-off, or reserved for special occasions. Nor does it undo the damage wrought by ten years of cuts.

'Colleagues will have heard the death knell for austerity pay policy rung out before. NHS dentistry now requires consistency and investment, so all providers and performers can see the benefit.'

\section{NHS practice values bounce back}

The latest NASDAL (National Association of Specialist Dental Accountants and Lawyers) Goodwill Survey statistics have just been released and as always, prove interesting reading. These statistics are produced on a quarterly basis and provide a useful snapshot of the dental practice sales market.

The survey for the quarter ending 30 April 2019 sees both changes and continuing trends. The average goodwill value of NHS practices has bounced back after seeing three successive quarters of reductions. They saw an average goodwill value of $149 \%$ of gross fees - up from $118 \%$ in the quarter ending 31 January 2019 (but still nowhere near the July 2018 high of $224 \%$ ).

Mixed practices also saw a big rise with an average goodwill value of $146 \%$ of gross fees - up 38\% from the previous quarter. Fully private practice sales held relatively steady at to an average goodwill value of $120 \%$ of gross fees. When taken as an average, goodwill figures as a percentage of gross fees across all types of practice, deals were reasonably constant - up $2 \%$ on the previous quarter. Valuations, which traditionally can be more volatile, were also relatively stable at $131 \%$ of gross fees - up from $126 \%$. This reflects a calm 12 months in terms of valuations.

Alan Suggett, specialist dental accountant and partner in UNW LLP who compiles the goodwill survey, said: 'It is interesting to note that NHS practice values are back up - I wonder whether with Brexit/No Brexit looming, banks are looking for any kind of certainty that they can find. Anecdotally, I also hear that banks are keen on practices with a significant plan income - in uncertain times it is perhaps natural to cling on to any reassurance that one can find.

'There are still plenty of private equity backed corporates paying big money if your practice is in the 'right' place. However, if you are a single-handed practice with a small NHS contract value and low UDA rate in Cumbria or Cornwall, I wouldn't hold your breath.'

The goodwill figures are collated from accountant and lawyer members of NASDAL on a quarterly basis in order to give a useful guide to the practice sales market. These figures relate to the quarter ending 30 April 2019.

NASDAL reminds all that as with any averages, these statistics should be treated as a guideline only. 